\title{
Pojęcie wzniosłości w filozofii Kanta
}

Niniejszy artykuł stanowi próbę przypomnienia, a zarazem interpretacji podstawowych wątków koncepcji wzniosłości zawartej w kantowskiej Krytyce władzy sądzenia. Źródłowa interpretacja Kanta odniosła się do takich wzbudzających wzniosłość zjawisk, które można byłoby wziąć za twory przyrody, albo proste dzieła sztuki. Wynikło to z epistemologicznych celów trzeciej z Kantowskich krytyk. W niniejszej interpretacji wykładnię tej koncepcji chciałbym wzbogacić o pewne odniesienia odczucia wolności do treści bezpośrednio psychologicznej. Problematyką tą zajmujemy się intensywnie w kręgu estetyków toruńskich.

Pytanie „czym inspirował się Kant tworząc swą koncepcję wzniosłości?” po dziś dzień pozostaje bez jednoznacznej odpowiedzi. Mirosław Żelazny w swojej książce Idea wolności w filozofii Kanta ${ }^{1}$ zauważa, że o ile wpływ Edmunda Burke’a na poglądy królewieckiego filozofa jest w tym wypadku bezspornym faktem, o tyle pozostałe inspiracje nie są już tak łatwe do odnalezienia. W sensie ogólnym zainteresowanie autora Krytyki czystego rozumu zagadnieniami dotyczącymi wzniosłości mogło wynikać po prostu z modnego w czasach gdy żył on i tworzył trendu. Sam bowiem zawarty w Krytyce władzy sądzenia opis tej wartości estetycznej, gdyby pominąć jej usytuowanie w systemie filozofii krytycznej, mimo całej swej oryginalności, w zasadniczych punktach nie różni się od koncepcji głoszonych przez myślicieli przedkantowskich.

\footnotetext{
${ }^{1}$ M. Żelazny, Idea wolności w filozofii Kanta, Toruń 1993, s. 148.
} 
Na wstępie swej prezentacji królewiecki filozof wprowadza ogólne odróżnienie wzniosłości od piękna, najpierw przedstawiając jednak ich wspólne cechy. Dowiadujemy się, że tak jedno, jak i drugie ma charakter bezcelowy i że obie kategorie nie zależą od sądów logicznych:

Piękno zgodne jest ze wzniosłością w tym, że jedno i drugie podoba się samo dla siebie, a następnie w tym, że jedno i drugie nie zakłada sądu zmysłowego ani logicznie określającego, lecz sąd refleksyjny²

Zdaniem Kanta objawiające się podczas percepcji obu wartości upodobanie wiąże się więc jedynie ze współgrającym z rozumem działaniem wyobraźni. Nie zachodzi tu natomiast możliwość odniesienia doświadczenia owego współgrania do jakiegoś konkretnego pojęcia.

Ponieważ jednak to nie cechy wspólne są przy prezentacji obu wartości najistotniejsze, filozof bardzo prędko przechodzi w swej prezentacji do dzielących je różnic. Piękno, twierdzi, w dużej mierze dotyczy cech jakościowych, wzniosłość odnosi się zaś właściwie wyłącznie do przedstawienia ilości.

Jeszcze istotniejszą różnicą wydaje się ta, która dotyczy oferowanych przez obie wartości typów rozkoszy. W przypadku piękna łączy się ona z poczuciem powabności. Przyjemność odczuwana przy przejawianiu się wzniosłości ma zaś diametralnie różny charakter. Omawiając ją, Kant pisze o nagłym zahamowaniu sił życiowych, a następnie równie nagłym ich przypływie. $\mathrm{Z}$ tego powodu rozkosz związana $\mathrm{z}$ odczuciem tego, co wzniosłe, nazwana zostaje przez niego rozkoszą negatywną. Umysł, który percypuje piękno czuje się przez nie pociągany, w konfrontacji z wzniosłością za każdym razem odczuwa też, że jest odtrącony. Tego typu odczucie, nazwane przez Żelaznego „odczuciem bólu i poniżenia”, przywodzi widza do wrażenia, że stoi on w obliczu czegoś godnego podziwu i szacunku. „Odczuwamy, że doświadczyliśmy czegoś, co nas - jako istotę empiryczną - niewymiernie przekracza”’3.

Najistotniejszą jednak różnicę pomiędzy obu omawianymi wartościami stwarza fakt, że wzniosłość nie może być cechą żadnego przedmiotu, ani nawet w ogóle nie może przybrać żadnej formy materialnej. Zdaniem Kanta to, co wzniosłe, może się odnosić wyłącznie do takich idei rozumu, których przedmiotowe wyobrażenie sobie nie jest możliwe. Jedynym, co jest tu wy-

\footnotetext{
${ }^{2}$ I. Kant, Krytyka władzy sądzenia, tłum. J. Gałecki, Warszawa 2004, s. 130.

${ }^{3}$ M. Żelazny, Idea wolności w filozofii Kanta, s. 148.
} 
obraźni dane są pobudzające tę ideę przedstawienia. Dobrego przykładu takiego stanu dostarcza obserwacja burzy na morzu:

Tak np. bezkresnego, wichrami smaganego oceanu nie można nazwać wzniosłym. Jego widok jest straszny i musiało się już [przedtem] wpoić w umysł różnego rodzaju idee, jeśli widok taki ma wzbudzić w nim uczucie, które samo jest wzniosłe dlatego, że pobudza umysł do odwrócenia się od świata zmysłów i zajęcia się ideami zawierającymi wyższą celowość

Zdaniem Kanta naturalne doświadczenia wzbudzające wzniosłość na ogół kojarzą się z chaosem i spustoszeniami, jakich może dokonać przyroda, a nie jak w przypadku piękna, z harmonią i porządkiem, dzięki którym możemy dostrzec analogię pomiędzy dziełem przyrody a dziełem sztuki.

W dalszej części swojej pracy królewiecki filozof dokonuje znanego podziału wzniosłości na matematyczną i dynamiczną. Pierwsza ma się odnosić do władzy poznania, druga zaś do władzy pożądania. W paragrafie 25 czytamy: „Wzniosłym nazywamy to, co jest absolutnie wielkie”.

Funkcji stwierdzenia rozmiaru czegokolwiek królewiecki filozof nie przypisuje ani czystemu pojęciu intelektu, ani też danym naocznym. O ile quantitas każdego obiektu możemy stwierdzić bez żadnych odniesień, twierdzi, to w przypadku magnitudo możliwość taka już nie zachodzi. Tu wielkość jesteśmy w stanie określić tylko na podstawie czegoś, co przyjmie rolę miernika. W konsekwencji zaś: „Żadne określenie wielkości zjawisk nie może w ogóle dostarczyć absolutnego pojęcia wielkości, lecz zawsze tylko pojęcie porównawcze"6.

Kant podkreśla, że stwierdzając, iż coś jest wzniosłe uznajemy, że to coś ma nieporównywalną z niczym innym wielkość, bo w tym ujęciu nie ma żadnego

\footnotetext{
${ }^{4}$ I. Kant, Krytyka władzy sądzenia, s. 133.

${ }^{5}$ Tamże, s. 136.

${ }^{6}$ Tamże. s. 137.
}

Jeśli można wprowadzić w tym miejscu akcent osobisty, odwołam się do pewnej animacji (Dostępna między innymi pod adresem internetowym: http://geek-life.com/wp-content/uploads/2010/10/EARTH_comparative_size.gif). Przedstawia ona rozmiar Ziemi oraz największej znanej ludziom gwiazdy YV Canis Majoris. Twórca animacji dokonał owego zestawienia, w ten sposób, że po kolei przedstawił rozmaite ciała niebieskie różniące się od siebie rozmiarem, ale nie na tyle, żeby niemożliwe było ich optyczne zestawienie. W przedstawieniu tym, wychodząc od najmniejszego, przywołanego ciała niebieskiego, czyli Ziemi dochodzimy do ogromnych rozmiarów gwiazd, cały czas zachowując wrażenie ciągłości narastających wielkości. Pozwala to w przybliżeniu uzmysłowić sobie wszystkie wielkości, które stały się przedmiotem eksperymentu. 
obiektywnego miernika, który mógłby rozmiar danego przedmiotu określić. Pozostaje więc miara wynikająca $z$ odniesienia podmiotowego, taka oczywiście, co do której można wysuwać roszczenia, że wszyscy się z nią zgodzą.

Jest to bardzo ważne zastrzeżenie: podmiotowe kryterium wielkości estetycznej mimo żądania jego powszechności nie nadaje się do oceniania wielkości w sposób logiczny. I nie chodzi w tym wypadku o żadną wielkość wymierną, lecz o samo stwierdzenie, że coś jest po prostu wielkie w stopniu wyższym aniżeli inne przedmioty tego samego gatunku. Według Kanta w takim przypadku możliwe jest obranie odpowiedniej, skali identycznej dla każdego człowieka. Nie jest tu też istotnym charakter żadnej innej przyjętej miary, jak bowiem czytamy:

Obojętne jest przy tym zresztą, czy miernik ten jest empiryczny, jak np. średnia wielkość znanych nam ludzi, zwierząt pewnego gatunku, drzew, domów, gór itp., czy też jest miernikiem danym a priori, który wskutek braków (Mängel) wydającego sąd podmiotu ograniczony jest do subiektywnych warunków unaoczniającego przedstawienia In concreto, takich np. jak w sferze praktycznej: rozmiary (Grösse) pewnej cnoty lub wolności politycznej i sprawiedliwości w pewnym kraju; lub w sferze teoretycznej: skala (Grösse) trafności czy nietrafności dokonywanej obserwacji lub pomiaru itp.?

Często się przydarza, że za wielki możemy uznać przedmiot, który skądinąd nic dla nas nie znaczy. Ważne jest jedynie, by swoim ogromem sprawiał, że się nam podoba oraz by oddziaływał na nasz umysł. Gdyby odwołać się do wiedzy współczesnej, dobrego przykładu dostarczałyby tu naziemne rysunki na pustyni Nazca ${ }^{8}$. Jak wiadomo, rysunków tych widz nie jest w stanie, patrząc z normalnej perspektywy, zobaczyć całości. Mimo to budzą one specyficzny podziw i to nie tylko ze względu na swą formę, lecz przede wszystkim na rozmach, z jakim zostały stworzone. Podziw dla wzniosłości nie dotyczy bowiem żadnego, wzbudzającego ją, konkretnego przedmiotu, ba, przedmiot taki czasem może być nawet pozbawiony formy. Upodobanie estetyczne wynika tu bowiem wyłącznie $\mathrm{z}$ „rozszerzania wyobraźni w sobie samej”.

\footnotetext{
${ }^{7}$ I. Kant, Krytyka władzy sądzenia, s. 138.

${ }^{8}$ Według Encyklopedii PWN: Nazca [nạska], płaskowyż w południowo-zachodnim Peru, w Kordylierze Nadbrzeżnej (Andy Środkowe), w dorzeczu rzeki Nazca; 400 (200?) p.n.e. - 600 n.e. kultura archeologiczna zw. kulturą Nazca (rzemiosło artyst., zwłaszcza ceramika i tkactwo); na płaskowyżu także gigantyczne rysunki naziemne, być może z VI w. n.e. - czas i cel ich powstania oraz związek z kulturą Nazca nie są znane.
} 
W przypadku sądów refleksyjnej władzy sądzenia istotne jest też, że określając $\mathrm{w}$ wyobraźni jakiś przedmiot jako wielki, równocześnie wyrażamy w stosunku do niego specyficzną formę szacunku. Kant pisze, że nawet piękno może być określone jako wielkie, bądź małe. Wynika to stąd, że w przypadku sądu estetycznego każde nasze przedstawienie stanowi pewną wielkość $\mathrm{w}$ znaczeniu quantum, to znaczy nieporównywalną z wielkością czegokolwiek innego.

Istotę faktu, że wzniosłym można nazwać tylko coś, czemu przypisuje się wielkość absolutną, określa królewiecki filozof następująco: „Rozumiemy od razu, że nie zgadzamy się na szukanie dlań adekwatnego miernika poza nim, lecz jedynie w nim samym".

Wzniosłość ma więc stanowić wielkość, którą można porównać jedynie do samej siebie. Kant stwierdza przez to, że nie jest ona jakąś należącą do przedmiotów cechą, lecz że jej uczucie wynika z naszych idei.

Tu pojawia się wiele wyjaśniająca definicja: „Wzniosłe jest to, w porównaniu z czym wszystko inne jest małe"10.

Napotykamy tu więc przeciwieństwo wyobrażenia wzniosłości jako cechy przysługującej samym przedmiotom przyrody. W przyrodzie zawsze bowiem istnieje możliwość ilościowego odniesienia czegoś do czegoś innego. Znaczy to, że od wszystkiego podanego jako przykład pewnej wielkości zawsze możemy znaleźć coś większego. Prawidłowość ta oddziałuje również w drugą stronę. Niezależnie od wszystkiego, wyobraźnią możemy bowiem sięgnąć do przedmiotów przynależnych do coraz niższych poziomów wielkości.

Żaden przedmiot empiryczny nie może więc, sam przez się być nazwany wzniosłym. W konsekwencji:

Wzniosłym należy przeto nazwać nastrój ducha, wywołany przez pewne zajmujące refleksyjną władzę sądzenia wyobrażenie, nie zaś sam przedmiot ${ }^{11}$.

oraz:

Wzniosłe jest to, czego sama tylko możliwość pomyślenia świadczy o istnieniu pewnej władzy umysłu, przekraczającej każdy miernik zmysłowy ${ }^{12}$.

\footnotetext{
${ }^{9}$ I. Kant, Krytyka władzy sądzenia, s. 139.

10 Tamże, s. 140.

11 Tamże.

12 Tamże, s. 141.
} 
Zachwyt wzniosłością wynika więc z faktu, że nasz umysł jest w stanie pomyśleć rzeczy [Sache], które go przerastają. Absolutnie wielkim jest to, jak do odczuwania przerastającego nas zjawiska potrafimy wykorzystać swą władzę sądzenia. Zdaniem Kanta wszelki inny sposób jej wykorzystania, w takiej sytuacji będzie w każdym względzie za mały.

I tak, aby w ogóle uzyskać coś, co uznamy za absolutnie wielkie, potrzebujemy nie matematycznej, tylko estetycznej oceny wielkości. Ta pierwsza zawsze bowiem pozostanie relatywna wobec wszelkich przyjmowanych przy jej określaniu miar, dopiero druga pozwala nam wytworzyć ideę czegoś wielkiego ponad wszelką liczbę.

W tym miejscu Kant wspomina o dwóch czynnikach koniecznych do tego, by jakaś ujmowana $\mathrm{w}$ wyobraźni ilość mogła stać się miernikiem służącym ocenie wielkości. Są to ujmowanie ${ }^{13}$ i scalanie ${ }^{14}$. Zdaniem filozofa o ile ujmowanie nie przysparza w tym względzie żadnych problemów, bo może się ono ciągnąć w nieskończoność, to problem scalania jawi się jako nieco trudniejszy. Ma ono bowiem swoje maksimum i tym bardziej się do niego zbliża im dalej posuwa się proces ujmowania. Owym maksimum ma być właśnie największy estetycznie, podstawowy miernik oceny wielkości. Dzieje się tak, gdyż ujmowanie po pewnym czasie po prostu wypiera dawniejsze elementy na rzecz nowych. Zdaniem Kanta wyobrażenie traci więc tu dokładnie tyle, ile zyskuje. Powyższe założenia pozwalają we właściwy sposób wytłumaczyć interesujące zjawisko, które zauważył napoleoński generał Savary, a które w Krytyce władzy sądzenia opisane jest w następujący sposób:

Aby w pełni przeżyć wzruszenie, jakie wywołuje wielkość piramid, nie należy ani za bardzo się do nich zbliżać, ani zbytnio od nich oddalać ${ }^{15}$.

Jeśli za bardzo oddalimy się od piramidy, to jej kontury stają się co do wielkości konturami czegoś nieokreślonego i ich widok nie będzie oddziaływał na sąd smaku. Kiedy natomiast stajemy zbyt blisko, nie mamy możliwości objęcia oglądem całości budowli. Nie odczujemy go, gdyż ujmowanie będzie wówczas oddziaływało z całą swą siłą, nie pozwalając scalaniu na wytworzenie wyobrażenia całości.

\footnotetext{
${ }^{13}$ Apprehensio.

${ }^{14}$ Comprehensio aesthetica.

${ }^{15}$ I. Kant, Krytyka władzy sadzenia, s. 143.
} 
Abyśmy mogli zacząć odczuwać wzniosłość, musimy więc znaleźć się w pewnym określonym punkcie, usytuowanym nie za daleko, ale również nie za blisko. Żelazny w książce Filozofia i psychologia egzystencjalna ${ }^{16}$, nazywa go, punktem Savary’ego, właśnie od nazwiska przytoczonego przez Kanta francuskiego generała.

Istota spojrzenia z punktu Savary'ego sprowadza się do przestrzennego usytuowania: nie za blisko obserwowanego obiektu, bo wtedy zobaczymy tylko zbiór szczegółów, ale i nie za daleko, bo wówczas nie będziemy w stanie ocenić matematycznej wielkości zjawiska ${ }^{17}$.

Żelazny zauważa, że położenie punktu Savary’ego (przynajmniej w odniesieniu do wielkości przedmiotów przyrody nieożywionej) pozostaje w relacji do wielkości ciała obserwatora. Oczywiste jest, że półtora metrowy mur z cegły może zrobić na małym dziecku wrażenie, jakiego nie zrobi na osobie o średnim wzroście, która bez problemu będzie mogła zobaczyć, od czego on ją oddziela. Kwestia wielkości ciała obserwatora, w przypadku sądów dotyczących wzniosłości matematycznej jest więc kwestią nadzwyczaj istotną. Ciało jest bowiem naszym pierwszym i pierwotnym punktem odniesienia. Porównujemy z nim kolejne przedmioty, z nimi następne i tak dalej. To, że w oglądzie wyobraźnią możemy dochodzić do obiektów o najbardziej monstrualnych rozmiarach, tak, jak chociażby we wspomnianej wcześniej w przypisie rozpisce ciał niebieskich, staje się właśnie źródłem wspomnianej rozkoszy, która pozwala naszemu umysłowi odczuć wzniosłość.

Przykład określony mianem punktu Savary'ego niekoniecznie musi jednak odnosić się wyłącznie do przyrody nieożywionej. Ponieważ Filozofia i psychologia egzystencjalna dotyczy głównie tematyki psychologicznej natrafiamy tu również na inne przykłady, o których Żelazny pisze, że:

nie chodzi w nich, przy przeżywaniu uczucia wzniosłości, o czyste zjawisko estetyczne, lecz o całokształt przeżyć, przez to wzmacnianych ${ }^{18}$.

W książce znajdujemy między innymi opis lotu helikopterem nad Wielkim Kanionem Kolorado. Bodźce, które docierają do nas, podczas takiej wycieczki, wywierają, zdaniem Żelaznego, przysłowiowe piorunujące wrażenie.

\footnotetext{
${ }^{16}$ M. Żelazny, Filozofia i psychologia egzystencjalna, Toruń 2011.

17 Tamże, s. 454.

${ }^{18}$ Tamże.
} 
Sam helikopter jest typem maszyny, która dzięki swoim niewielkim rozmiarom, ale i dużym możliwościom manewrowania pozwala „spojrzeć na świat z punktu Savary'ego".

Ale co ciekawe, punkt ten, może być rozpatrywany również w perspektywie relacji międzyludzkich. Oddalamy się więc od świata przyrody nieożywionej po to, by skupić się raczej na zagadnieniu, w jaki sposób jeden człowiek może zostać porażony wręcz wielkością drugiego. Żelazny rozważa tu trzy przypadki. Pierwszy charakteryzuje jako:

Dążenie do wynajdywania sytuacji, kiedy doszukiwanie się wielkości w innej osobie będzie nam sprawiać rozkosz ${ }^{19}$.

Rysuje się tu jednak również druga możliwość, już nie tak pozytywna, granicząca z czymś, co określa się mianem manii wielkości czy też nieszczęsności psychicznej wyrastającej z tęsknoty za zwracaniem na siebie większej uwagi.

Może chodzić też o udane, mniej udane, lub zgoła żałosne dążenie do tego, by samemu tak się sytuować względem innych, iż będą mnie oni postrzegać z pozycji punktu Savary'ego ${ }^{20}$.

Opcję taką Żelazny nazywa „swoistym rozdwojeniem jaźni”. Pojawia się ono: „gdy pragnę z takiego punktu [Savary’ego] postrzegać samego siebie jako osobę wielką"21.

Taka postawa może być uznana wręcz za paranoiczną. Przejawiające ją osoby, jak pisze Żelazny, posiłkując się koncepcją Binswangera, czynią wszystko co mogą, ażeby bez przerwy mogły być przez innych postrzegane właśnie z punktu Savary’ego. Często zdarza się, że ich zachowanie jest skutkiem ubocznym praktyk biznesowych i politycznych. Człowiek staje się tu swoistym towarem-bożyszczem, który ma się sprzedać. W rozdziale zatytułowanym Transcendentalna koncepcja nieszczęsności Żelazny wymienia przykłady takiego typu kreowania własnej postaci. Są to między innymi: wielki nieobecny, oko Opatrzności, ptak wolności czy też po prostu heros. Nierzadko zdarza się, że osoby odgrywające takie role zaczynają się z nimi do tego stopnia identyfikować, że maska, jak to się mówi kolokwialnie, „przyrasta im wręcz twarzy”. Nie są już one wówczas w stanie żyć w sposób inny, aniżeli

\footnotetext{
19 Tamże, s. 456.

${ }^{20}$ Tamże.

${ }^{21}$ Tamże.
} 
tak, jak żyją kreowane przez nich domniemane postacie. Jak długo otoczenie odbiera takie zachowanie jako rzekomo naturalny sposób bycia, wszystko wydaje się w porządku. Od pewnego momentu jednak osoba starająca się odgrywać rolę jakiejś postaci patetycznej może zostać w oczach postrzegającego go otoczenia, zdegradowana do postaci błazna. Zdaniem Żelaznego przyczyn takiego stanu rzeczy należy między innymi doszukiwać się w tym, że:

[taki człowiek] sam najczęściej dopatruje się w tym, że swą rolę grał jeszcze nienajlepiej i w efekcie jeszcze głębiej zapada się w wyobrażenia swej wymarzonej wielkości stając się postacią coraz bardziej komiczną lub żałosną ${ }^{22}$.

Istnieje jednak jeszcze jedna możliwość. Postać taka może bowiem czasami nie tyle śmieszyć, co przerażać. Szczególnie uwidacznia się to, gdy marzy ona nie tylko o podziwie, ale też o władzy.

Patrząc z punktu Savary’ego, inną osobę możemy oczywiście przedstawiać sobie, zarówno pozytywnie, jak i negatywnie. Pozytywnie, gdy postrzegamy ją jako radzącą sobie w nazbyt dla nas skomplikowanym świecie, którego do końca nie rozumiemy. Inaczej wygląda natomiast sytuacja, gdy ta budząca w nas podziw osoba sprawia, że pragniemy się jej całkowicie podporządkować. Nasza fascynacja przybiera wówczas formę masochizmu. Okazuje się, że nawet kat-morderca, jeśli jest na przykład ładnie ubrany, a zwłaszcza kiedy dobrze radzi sobie w okrutnym dla nas świecie, może się przyczynić do odczuwania przez nas wzniosłości. Bywa, że ów masochizm prowadzi do opisywanej przez Żelaznego „żałoby po porzuceniu”. Sprowadza się ona, do ciągłego postrzegania z punktu Savary’ego kogoś, kogo porzucona osoba bardzo kochała. Pisze on o takowej sytuacji w następujący sposób:

Mechanizm opisanego powyżej nieszczęsnego myślenia znowu daje się wyjaśnić jako wola sensu. Osoba cierpiąca nie może wystąpić przeciw temu, kto jest naprawdę winien jej cierpieniu, bo go kocha ${ }^{23}$.

Prowadzi to do bardzo negatywnego myślenia, a mianowicie do upatrywania całej winy za fakt odrzucenia w sobie. Osoba porzucona zaczyna z maniackim uporem szukać swych przewinień i błędów, które ją doprowadziły do smutnej sytuacji. W najgorszych przypadkach, taka "choroba na miłość" może się nawet kończyć tragicznie. Osoba cierpiąca, może zwyczajnie zacząć zapominać o swych podstawowych potrzebach życiowych.

\footnotetext{
22 Tamże, s. 457.

23 Tamże, s. 464.
} 
Jak zauważa Żelazny, nawet sytuacja odzyskania w jakiś sposób swojego wielce umiłowanego, idealnego partnera nie musi kończyć tu nieszczęścia. Może się okazać, że pomimo ponownej, pozornej tym razem bliskości, dawny porzucony nie będzie potrafił patrzeć na swojego partnera z pozycji innej niż punkt Savary’ego. Wciąż będzie przejawiał strach przed ponownym porzuceniem. Innym przypadkiem może być sytuacja rozczarowania. Tu cała sytuacja może przebiegać odwrotnie. Ofiara staje się swojego rodzaju katem. Człowiek, obserwowany przez nią dotychczas z pozycji dającej mu niemalże boskie cechy, nagle okazuje się kimś zwyczajnym. W jego osobowości uwidaczniają się „bloki piramidy”, czyli zwykłe ludzkie wady. To nie o takiego kogoś starał się ktoś, kto go wcześniej utracił, a teraz odzyskał. Może dojść więc do sytuacji, w której dumna ofiara żałoby po porzuceniu, „będzie się mściła na partnerze za to, że w jej wyobrażeniu oszukał ją".

Czy jest to rzeczywiście prawdziwa miłość? Wedle słów Żelaznego:

Prawdziwy autorytet nie wymaga uzasadnienia. Jeśli ktoś będzie nim dla nas rzeczywiście, nie zapomnimy, kim jest, nawet „stojąc u stóp piramidy”, czyli postrzegając poszczególne fakty jego codziennego życia ${ }^{24}$.

Innym przypadkiem takowej nieszczęśliwej miłości związanej z niemożnością opuszczenia punktu Savary’ego jest sytuacja, w której osoba cierpiąca nawet nie zna tego, kto jawi się jej jako wielki. Taki typ osobowości przejawiają na przykład niewiasty określone mianem kobiety fatalnej (femme fatale). Nieszczęście kogoś takiego polega na tym, że przez całe życie szukają swego jedynego mężczyzny, wybranego i idealnego, po to, aby w samych marzeniach, zaraz po poznaniu, stać się jego niewolnicą. Problem zaczyna być niebezpieczny, gdy taka kobieta przypadkowo spojrzy na kogoś, właśnie z perspektywy punktu Savary'ego. Zobaczywszy go i pozyskawszy jego względy, zaczyna natomiast dostrzegać, że ów idealizowany mężczyzna przejawia zwyczajne, ludzkie wady. Wobec takiego załamania ideału kobieta fatalna jest w stanie nawet go znienawidzić, bo w jej przekonaniu okropnie ją oszukał. W rzeczywistości jednak to ona oczywiście oszukała tu samą siebie, gdyż dopasowywała swoje sądy i uczucia do pragnień, które to zjawisko, gdy przybiera rozmiary patologiczne określane jest mianem katatymii.

Skąd się biorą zaś takie potrzeby zdobycia mężczyzny-wojownika, wielkiego i pięknego? Przypuszczalnie z zamierzchłych czasów, kiedy to rzeczy-

${ }^{24}$ Tamże, s. 466. 
wiście silny wojownik potrafił obronić swą kobietę przed wszelkimi niebezpieczeństwami oraz zapewnić jej i jej potomstwu bezpieczny byt. Zdaniem Binswangera normalne psychicznie kobiety nie powinny jednak przejawiać tego typu potrzeb, a przynajmniej nie powinny ich one przytłaczać.

Innym typem wzniosłości opisywanym przez Kanta jest wzniosłość dynamiczna. Już na samym początku poświęconego temu zagadnieniu 28 paragrafu Krytyki władzy sądzenia opisane zostały dwie władze: potęga i przemoc. Potęga, jak pisze Kant, jest to: „Władza, która ma przewagę nad dużymi przeszkodami" 25 .

Aby stać się przemocą, musi ona oznaczać nie tylko przewagę bierną, lecz również czynną, mogącą przeciwstawić się oporowi innej potęgi. Ale zdaniem królewieckiego filozofa potęga przyrody po to, by mogła być nazwana wzniosłą, nie powinna mieć nad nami przemocy. Podstawowym czynnikiem pozwalającym uznać jakieś zjawisko przyrody za rodzące uczucie wzniosłości dynamicznej jest więc możliwość wyobrażenia sobie go jako budzącego lęk. Kant zaznacza jednak, że nie każde budzące lęk zjawisko będzie od razu, $\mathrm{z}$ tego tylko powodu, określane przez nas $\mathrm{w}$ ramach sądu estetycznego jako wzniosłe. Sam lęk bierze się tu z sądów na temat wielkości oporu, jaki dany przedmiot czy zjawisko może nam stawiać. A przecież coś, co chce się nam przeciwstawiać, bardzo często uznawane jest przez nas za złe. Kiedy uświadamiamy sobie, że nie jesteśmy w stanie temu czemuś sprostać, pojawia się uczucie lęku. Dlatego:

Dla estetycznej władzy sądzenia może więc przyroda o tyle tylko uchodzić za potęgę, a tym samym za dynamicznie wzniosłą, o ile rozważana jest jako przedmiot wzbudzający lęk $k^{26}$.

Jednakże, jak zauważa Kant, „kto się lęka, nie może wydać sądu o wzniosłości w przyrodzie”. W obliczu czegoś przerażającego raczej będziemy więc starali się tego czegoś uniknąć i mieć z nim jak najmniej do czynienia. $\mathrm{Na}$ przykład znajdując się pośrodku rozszalałego sztormem oceanu nie będziemy mieli głowy do dywagacji na temat jego potęgi. Zamiast uczucia wzniosłości objawi się w nas wówczas raczej instynkt samozachowawczy albo też wyrzuty sumienia, powodowane możliwością rychłej utraty życia. Jeśli taką burzę uda się nam przeżyć, najprawdopodobniej niechętnie sięgać będziemy

\footnotetext{
${ }^{25}$ I. Kant, Krytyka władzy sadzenia, s. 156.

${ }^{26}$ Tamże, s. 157.
} 
do wspomnień na jej temat, mimo ulgi i radości towarzyszących uwolnieniu się od niebezpieczeństwa. Kant zauważa jednak, że coś można uznawać za budzące lęk, a jednocześnie się tego czegoś nie bać.

[Dzieje się to wtedy], gdy oceniamy przedmiot w ten sposób, że jedynie w myśli przedstawiamy sobie wypadek, że gdybyśmy chcieli stawić temu opór, wszelki opór okazałby się zupełnie daremny ${ }^{27}$.

Jako przykład zostaje tu podany Bóg. Człowiek cnotliwy boi się Boga, ale nie lęka się go. Wynika to stąd, że znając jego potęgę, nie potrafi sobie nawet wyobrazić sytuacji, w której złamałby jakieś przykazanie, narażając się tym samym na jego gniew. Ale mimo niemożności takiego wyobrażenia sobie wspomnianej sytuacji, ów człowiek wciąż pozostaje świadomy faktu, że takie sprzeniewierzenie może jednak kiedyś nastąpić.

Innym sposobem odczuwania wzniosłości w obliczu potęgi przyrody jest przywołana już obserwacja groźnych zjawisk z bezpiecznego miejsca. O ile wydawaniu jakichkolwiek sądów estetycznych nie sprzyja na przykład fakt, że widz znajduje się pośrodku rozszalałego oceanu, o tyle obserwacja tego samego żywiołu z punktu usytuowanego na wybrzeżu osądom takim sprzyja. Jako inne przykłady przytacza też Kant strzeliste szczyty gór, chmury burzowe, eksplodujące wulkany oraz wysokie wodospady potężnych rzek. Patrząc na wszystkie te zjawiska, możemy bardzo prędko uświadomić sobie, że $\mathrm{w}$ konfrontacji z ich potęgą, nie mielibyśmy żadnych szans. Ale zdaniem filozofa $\mathrm{z}$ perspektywy wartości estetycznych to nas w nich właśnie najbardziej pociąga.

Dlatego też przedmioty takie chętnie nazywamy wzniosłymi, gdyż podnoszą moc naszej duszy ponad jej zwyczajną, przeciętną miarę i pozwalają nam odkryć w sobie zupełnie innego rodzaju zdolność do stawiania oporu, która ośmiela nas do tego, by zmierzyć się z pozorną wszechmocą przyrody ${ }^{28}$.

Samo pojęcie „bezpiecznej odległości” jest w tym kontekście względne. W Idei wolności w filozofii Kanta Żelaznego można znaleźć twierdzenie, że takowego bezpiecznego miejsca w ogóle nie ma:

\footnotetext{
${ }^{27}$ Tamże, s. 157.
}

${ }^{28}$ Tamże, s. 158. 
O ile jednak którekolwiek z wymienionych zjawisk mamy możność obserwować $\mathrm{z}$ całkowicie bezpiecznego miejsca, to, co przerażające, staje się natychmiast czymś pociągającym. W perspektywie całości ludzkiego życia nie dysponujemy jednak takim bezpiecznym miejscem. Człowiek jako jednostkowa istota empiryczna okazuje się wobec ogromu przyrody zjawiskiem tak kruchym i nikłym, że trudno tu mówić nawet o jakiejkolwiek skali porównawczej ${ }^{29}$.

Tu pojawia się pytanie: jeżeli mielibyśmy świadomość, że przebywamy $\mathrm{w}$ takim całkowicie bezpiecznym miejscu, to czy to, co teoretycznie wzniosłe, nadal budziłoby odczucie wzniosłości? Sam Kant był zdania, że ciemne przedstawienia lęku dręczyłyby nas nadal. Na przykład w Antropologie Mrongovius czytamy o wąskiej kładce, o której rozum mówi nam, że jest bezpieczna, a mimo to boimy się przez nią przejśćc ${ }^{30}$. Nie wszystkie jednak moce naszego świata wyznaczane są siłą fizyczną. Potęga, jaką jest przyroda, pozwala nam bowiem odkryć „władzę sądzenia o sobie, jako niezależnych od przyrody”. Umysł nasz nawet $\mathrm{z}$ nieskończoności, którą cechować miałaby się przyroda, potrafi zrobić jednostkę miary. Już sam fakt, że jesteśmy w stanie uzmysłowić sobie taką siłę, napełnia nas uczuciem wzniosłości. Żelazny zauważa wynikającą stąd istotną prawdę odnoszącą się do moralności. Kant pisze bowiem, że wobec uświadomienia sobie potęgi przyrody, wszystkie przedmioty trosk doczesnych zaczynają jawić się nam jako małe. Dzieje się tak, gdyż ostatecznie wzniosłym okazuje się nie to, co budzi w nas lęk, ale to, że nasz umysł potrafi sobie z wyobrażeniem tego czegoś poradzić:

Przyrodę nazywamy więc tutaj wzniosłą jedynie dlatego, że wznosi ona wyobraźnię do unaoczniającego przedstawienia takich wypadków, w jakich umysł może odczuć własną wzniosłość swego powołania i [swą wyższość] nawet nad przyrodą ${ }^{31}$.

Tak więc jak możemy przeczytać u Żelaznego, Kantowi nie chodzi tu o zrobienie z nas ascetów, w ogóle nie zwracających uwagi na kwestie dóbr doczesnych, a dążących jedynie do osiągnięcia jakiejś absolutnej szczęśliwości, ale o fakt, że owe dobra nie powinny kolidować z ideami dla ludzkości dużo ważniejszymi.

\footnotetext{
${ }^{29}$ M. Żelazny, Idea wolności w filozofii Kanta, s. 152.

${ }^{30}$ I. Kant, Anthropologie Mrongovius, Akademie Ausgabe, t. 25, s. 1222.

${ }^{31}$ I. Kant, Krytyka władzy sq̨dzenia, s. 159.
} 
Kant podkreślał jedynie wielokrotnie, że żadne cele świata doczesnego nie dadzą się pomyśleć jako ostateczne cele zaistnienia człowieka i dlatego nic, co doczesne, nie może nam przesłaniać celu nadrzędnego, na który wskazuje imperatyw kategoryczny, a którego realizacja da się pomyśleć tylko w formie idei regulatywnych ${ }^{32}$.

W Analityce wzniosłości poznajemy odpowiedź na pytanie dotyczące kwestii naszego bezpieczeństwa w obliczu potęgi natury. Kant słusznie zauważa, że skoro po to, by odczuć wzniosłość musimy znajdować się w miejscu, w którym nic nam nie grozi i sytuacji, w której stajemy sam na sam z ogromem natury nie wyobrażamy sobie "na serio", to czy "na serio” może być w tym wypadku odczuwana wzniosłość? Filozof stwierdza, że:

Upodobanie bowiem dotyczy tu tylko ujawniającego się w takich wypadkach powołania naszej władzy jako dyspozycji zawartej w naszej naturze; natomiast rozwinięcie i wyćwiczenie jej pozostawione zostało nam samym i stanowi nasze zadanie ${ }^{33}$.

Okazuje się więc, że nie jest istotne, czy jakaś fala zaraz zmiecie nas z powierzchni ziemi, czy też na falę tę możemy popatrzeć z całkowicie bezpiecznego miejsca. Chodzi o samą możliwość odczuwania przez nasz umysł „własnej wzniosłości swego powołania i [swej wyższości] nawet nad przyrodą".

Kant odwołuje się tu do przykładów dających się zaobserwować nawet u dzikich plemion. $\mathrm{W}$ ich społecznościach najbardziej godny podziwu bywa człowiek, który niczego się nie boi i nie cofa się przed przeciwnościami mężnie stawiając im opór. Filozof zauważa, że wartości tego typu są ważne również w ówczesnym świecie. Jak pisze:

Nawet w najbardziej cywilizowanym stanie zachowuje się nadal ten szczególnie wysoki szacunek dla wojownika; [...] a wszystko właśnie dlatego, że poznaje się po tym, iż umysł jego nie cofnie się przed niebezpieczeństwem ${ }^{34}$.

Dlatego też zdaniem Kanta większy podziw budzić będzie w nas wódz, aniżeli mąż stanu (przynajmniej jeśli chodzi o ocenę estetyczną). Ba, również wojna może być uznawana za uwznioślającą, o ile prowadzące ją strony

\footnotetext{
${ }^{32}$ M. Żelazny, Idea wolności w filozofii Kanta, s. 153.

${ }^{33}$ I. Kant, Krytyka władzy sądzenia, s. 160.

${ }^{34}$ Tamże.
} 
dbają o zachowanie porządku i praw. Dzieje się tak, gdyż zdaniem filozofa długotrwały brak konfliktów zbrojnych prowadzi do nastawiania się ludzi na handel, zarobek i wartości niższe. Jak sam pisze:

Długotrwały pokój wiedzie zazwyczaj do panowania samego tylko ducha handlu, a wraz z nim do panowania niskiej chciwości, tchórzostwa i zniewieściałości oraz do upodlenia się sposobu myślenia narodu ${ }^{35}$.

Wojna tym bardziej nas uwzniośla, im większe mają być niebezpieczeństwa stawiane przed narodem, na który ów konflikt spadł.

Pod koniec 28 paragrafu Krytyki władzy sądzenia, wypowiada się Kant na temat wzniosłości dynamicznej w religii. Jak zauważa, siła Boga najczęściej przedstawiana jest jako żywioł natury: może to być biblijny potop lub zaćmienia słońca i nieokiełznane burze, mające wyrazić rzekomy gniew bogów. Zdaniem filozofa zachodzi tu coś zgoła innego aniżeli w opisanych wcześniej przypadkach. Wzniosłość nie wynika w tym wypadku ze świadomości, że nasz umysł jest w stanie coś ogarnąć. Pojawia się natomiast jego wszechobecna niemoc wobec potęgi, którą widzimy:

W ogóle w religii padanie na ziemię, okazywanie czci pochyloną głową, wśród gestów i wykrzykiwań pełnych skruchy i lęku, zdaje się być jedynym odpowiednim zachowaniem się w obecności bóstwa i dlatego też przeważająca większość ludów przyswoiła sobie to wszystko i dotąd przestrzega ${ }^{36}$.

By jednak odczuć wzniosłość wiążącą się bezpośrednio z obcowaniem z bóstwami, konieczne okazuje się, tak jak w przypadku każdego innego rodzaju wzniosłości, by nie wzbudzała ona lęku. Zdaniem Kanta człowiek grzeszny nie jest w stanie odczuwać wzniosłości, bo jest świadomy jak potężny jest Bóg, któremu się sprzeciwił, i jaka za to sprzeniewierzenie czeka go kara. Bardzo istotna będzie przy tym świadomość, że Bóg jest miłosierny. Człowiek, który w jego działaniach dostrzega dobrą i szczerą intencję, nie będzie się bał, to zaś pozwoli mu na odczucie wzniosłości idei boskości w całej jej pełni. Zdaniem Kanta nawet pokora jest formą wzniosłego nastroju umysłu. Jest ona bowiem świadomością własnych braków, do których przyznajemy się z całą surowością. I mimo, że nasz umysł cierpi z jej powodu, pozostajemy w świadomości, że najważniejsze jest byśmy mogli stać się lepszymi.

\footnotetext{
${ }^{35}$ Tamże, s. 161.

${ }^{36}$ Tamże.
} 
Tym właśnie ma się różnić prawdziwa wiara od zabobonu. Ten drugi może wzbudzać jedynie lęk. Nie pozostawia miejsca na uwznioślający wyznawców podziw. Towarzyszy mu tylko strach, poczucie uległości i niemocy wobec potężnego bóstwa, które wcale nie cieszy się szacunkiem. Na poparcie takiej wizji można byłoby przytoczyć wiele przykładów: czy to greckiego pana podziemi Hadesa, czy perskiego Arymana, boga ciemności i demonów. Takim istotom można się jedynie „podlizywać” i błagać je o łaskę. Nie ma tu miejsca na „religię cnotliwego żywota”.

Pod koniec omawianego paragrafu natrafiamy ostateczne na stwierdzenie, że wzniosłość nie jest cechą żadnego przedmiotu, lecz istnieje wyłącznie w naszym umyśle. Kant zauważa, że dopóki jesteśmy w stanie zrozumieć swą przewagę nad przyrodą dopóty możemy odczuwać napełniające nas z tego powodu wrażenie wzniosłości.

I tylko przy założeniu tej idei w nas i odniesieniu do niej jesteśmy zdolni dojść do idei wzniosłości owej istoty, która wywołuje w nas głęboki szacunek nie tylko przez swą potęgę, jaką okazuje w przyrodzie, lecz bardziej jeszcze przez daną nam zdolność wydawania bez lęku sądu o potędze przyrody oraz możności myślenia o naszym powołaniu, jako o czymś, co jest wyższe od niej

W tym miejscu Kant przechodzi do rozważań dotyczących modalności sądu o wzniosłości przyrody (taki właśnie tytuł nosi paragraf 29 Krytyki władzy sadzenia).

Na samym jego początku filozof zauważa, że po to, by móc wydać o naturze sąd dotyczący wzniosłości konieczna jest jakaś charakteryzująca nasze władze poznawcze wyższa kultura. Inaczej niż w przypadku sądu o pięknie, nie należy się tu spodziewać zgodności naszego zdania ze zdaniem innych ludzi. Kant wymienia dwa konieczne do możliwości wydania sądu o wzniosłości warunki, są to mianowicie odpowiedni nastrój umysłu oraz wytężenie wyobraźni. Pierwszy z nich ma się cechować wrażliwością na idee, a zwłaszcza na poczucie „nieadekwatności przyrody w stosunku do [tychże idei]”. Wyobraźnia z kolei potrzebna jest po to, by móc „traktować przyrodę jako schemat". Im bardziej to, co postrzegamy, odbiega od idei, którą o tym czymś mamy, tym poczucie wzniosłości jest silniejsze. Kant wspomina tu wręcz o gwałcie rozumu na zmysłowości. Doznając go, ludzie przygotowani i od-

37 Tamże, s. 163. 
powiednio świadomi są $\mathrm{w}$ stanie nazywać wzniosłymi zjawiska, które przez „tych bardziej prymitywnych” zostaną uznane po prostu za straszne, trudne i ogólnie nieprzyjemne. Królewiecki filozof posiłkuje się tu przykładem Horace-Bénédicta de Saussure, szwajcarskiego przyrodnika, będącego członkiem jednej z pierwszych wypraw na Mount Blanc, który w Voyages dans les Aloes opisał spotkanie z pewnym sabaudzkim chłopem. Ten w żaden sposób nie potrafił zrozumieć alpinistów udających się w nieprzystępne rejony gór. Otwarcie określał ich mianem wariatów. Zdaniem Kanta miałby on rację w przypadku, gdyby ludzie ci godzili się na owe niebezpieczne wyprawy tylko i wyłącznie ze względu na zamiłowanie do ryzyka. Ale jak sam zauważył tutaj cele były zgoła odmienne. Chodziło bowiem o „oświecanie ludzi” i ktoś taki jak de Saussure mógł ruszyć na wyprawę właśnie ze względu na kulturę swojej duszy, co później pozwoliło mu stworzyć doskonałe opisy swojej drogi na szczyt.

Jednak to nie sama kultura warunkuje sąd o wzniosłości. Ten może i jej wymaga, jednak jego podstawą jest ludzka natura:

Ma on (sąd) swą podstawę w naturze ludzkiej, mianowicie w tym, co wraz ze zdrowym rozsądkiem przypisać można każdemu człowiekowi i od niego wymagać - w dyspozycji do odczuwania idej (praktycznych), to jest [w dyspozycji] do tego co moralne ${ }^{38}$.

Wynika z tego, że ostatecznie odczuwanie wzniosłości może stać się udziałem każdego z nas.

\section{Abstract \\ The Notion of the Sublime in Kant's Philosophy}

Key words: Kant, the sublime, modern philosophy, esthetics, Critique of Judgment

The article is an attempt not only to refer again, but also interpret some pivotal elements of the concept of sublimity presented in Kant's Critique of Judgment. Kant presented a source interpretation of the category referring to sublime phenomena of

${ }^{38}$ Tamże, s. 165. 
nature or simple works of art, but such delineating of the field of interest was caused by the epistemological aims of the third Critique. In this presentation I would like to widen Kant's interpretation of the conception and add some references of the sense of freedom to the content of psychological character. This problems are a subject of intensive research among Torun aestheticians. 